\title{
Victim Rights in Stolen Property In California
}

\author{
Joseph P. Busch III†
}

In 1975 the California Legislature revised the law controlling the return of stolen property to its owner. This Comment contrasts the former law with the new statute and discusses the latter's implementation. The author finds that, although the new law adds significantly to the rights of victims of crime, it presents a number of technical and constitutional difficulties, and he proposes amendments to resolve these problems.

The storage and disposal of property alleged to be stolen and acquired during the course of a criminal investigation by the police or introduced into evidence by the prosecution gradually has becoine a problem in California. ${ }^{1}$ Police and court property rooms are often overcrowded, ${ }^{2}$ and these custodial agencies are seldom notified of the

$\dagger$ B.A. 1970, Claremont Men's College; J.D. 1976, Boalt Hall School of Law. The author, while working for the Àlameda County District Attorney's Office, drafted the original version of the 1975 amendments to CAL. PENAL CODE $\S 1413$, which is the subject of this Comment. The opinions expressed herein are solely those of the author and do not necessarily reflect those of the statute's sponsor, State Senator Nicholas Petris.

1. For example, in Alameda County, California, 75.2 percent of the crimes against civilian victims or personal property for which felony informations are filed or felony grand jury indictments brought involve some form of property loss due to theft. Police departments in Alameda County recover sone or all of the missing property in 52.9 percent of these cases. ALAMEda COUNTY Districr ATtORNeY's OFFice, Victim \& WrTnEss SuRveY 13 (July 1975) [hereinafter cited as VICTIM SURveY], on file at the California Law Review. The VICTIM SURVEY was a project sponsored by the National District Attorneys' Association and funded by the Law Enforcement Assistance Administration.

All statistics are drawn froin Alameda County, California. Similar information from other parts of the country is not available. There is no reason, however, to believe that the imcidence of crime and the response to it in Alameda County is not typical of that found in other urban and suburban areas of the country. Alameda County has a population of about 1,142,000. Alameda County PlaAnning DeP'T, Preliminary Estimates of Population, Apr., 1975. In 1974 there were 91,585 Part I crimes (major crimes agaimst the person or property) reported in Alameda County and 2,263 defendants were beld to answer for felonies during that period. VICTIM SURveY at 5.

2. For the Alameda County Superior Court and the Oakland Police Department, the storage problein has becoine so troublesome that additional space is being sought for each agency's property room. At the superior court, the property storage room occupics about one-quarter of the usable floor space in the building's ground floor and plans have been approved tentatively to expand the storage facility to use half of the space. At the 
disposition of a criminal case. ${ }^{3}$ As a result, in a significant number of cases stolen property is never returned to its owner. ${ }^{4}$ Even where property is eventually returned, victims are often deprived of the possession and use of their property for inonths and years at a time. ${ }^{5}$

The California legislature last year recognized the callousness of treating victims in this fashion. ${ }^{8}$ The provisions of California Penal Code section 1413 were amended to allow police to return stolen property to the owner prior to trial by a rapid administrative process with the protections of ultimate judicial control. ${ }^{7}$ This solution is a radical departure from California's previous approach to the problem, ${ }^{8}$ which

Oakland Police Department, the storage facility occupies approximately one-sixth of the usable space of the department's ground floor in a nine floor facility, and plans are being considered to double the storage space available. Interview with Howard A. Janssen, Alameda County Deputy District Attorney and Director of the Alameda County District Attorney's Victim/Witness Assistance Bureau, in Oakland, Aug. 15, 1975 [hereinafter cited as Janssen Interview], on file at the California Law Review.

3. Prior to February, 1975, no law enforcement agency in Alameda County was systematically notified of case disposition. Information gathered by the Alameda County District Attorney's Victim/Witness Assistance Bureau in January, 1975, from district attorneys in California revealed that failure to give such notice was common throughout the state. Janssen Interview, supra note 2.

4. Stolen property in Alameda County is not returned in 29.6 percent of the instances where it is recovered by the police. VICTM SURVEY, supra note 1, at 15.

5. The average length of time that a person is deprived of the use of property which has been stolen and recovered in Alameda County is 94 days. Id. at 15. It is not uncommon for property to be retained for a couple of years, even after the resolution of an appeal in a case. Janssen Interview, supra note 2.

6. See Report of Comm. Counsel on Senate Bill 1212, California Senate COMm. on Judiciary, on file at the California Law Review.

7. Cal. Penal Code $\$ 1413$ (West Supp. 1976). All references to code sections in the text of this Comment are to the California Penal Code.

8. The only other jurisdiction in the United States to have a similar procedure for the return of stolen property is the District of Columbia. D.C. CODE ANN. $\$$ 4-153 to -157 (1973). District of Columbia Code section 4-156 provides that the police property clerk shall deliver stolen property to a claimant upon satisfactory proof of ownership. The section also requires that notice be sent by registered mail to any other known claimant and directs the clerk to conduct an evidentiary hearing to determine the identity of the owner. The District of Columbia statute served as the inodel for California Penal Code section 1413. See Memorandum from Howard Janssen and Joe Busch to Dick Iglehart (legislative representative for the California District Attorneys' Association), Apr. 2, 1975, on file at the California Law Review. The Victim/Witness Assistance Bureau is the source for the present version of section 1413. See REPort of CoMm. Counsel on Senate Bill 1212, California Senate Comm. on Judiciary, on file at the California Law Review.

A survey of other jurisdictions reveals the following approaches to the return of stolen property: Six appear to follow the previous California model of judicial control over the return of property with notice to the defendant. C.Z. CoDe tit. 6, $\$$ 4901-04 (1963); Ky. Rev. Stat. ANN. $\$ \$ 431.200-.210$ (1975); LA. Rev. Stat. ANN. $\$ 15: 41$ (1967); Mo. Stat. ANn. \& 542.301 (Supp. 1975); PA. Stat. ANN. tit. 19, § 982 (1964); and WIS. STAT. ANN. $\$ 968.20$ (1971). Seventeen jurisdictions require a court order to return property but do not afford notice to the defendant. ARIZ. REV. STAT. ANN. \$ 131471 (1956); ARK. Stat. ANN. \$§ 43-2901 to -2906 (1964); ConN. GeN. StaT. ANN. § 
required a court order before stolen property could be returned to its owner. ${ }^{9}$

Part I of this Comment discusses how the law presently operates in restoring stolen property to its owner. The central focus is on the differing treatments afforded stolen property when the question of its return arises after it is seized pursuant to a search warrant but before it is admitted into evidence, after it is seized without a search warrant but before it is admitted into evidence, and, finally, after it is placed into evidence. Part II discusses the operational problems of implementimg section 1413. Part III analyzes the constitutional issues raised by the new statute. Finally, part IV contains specific proposals for amending section 1413 to cure the defects previously considered.

\section{Statutory Provisions}

\section{A. Stolen Property Not Yet Admitted into Evidence}

Section 1536 requires that property, stolen or otherwise, seized pursuant to a search warrant be held subject to the order of the court that issued the search warrant or of any other court having jurisdiction over the criminal case. ${ }^{10}$ Although section 1536 makes no provision

29-24 (1975) (cash only); Guam Penal Code $\S \S 1407-10$ (1970); IDAho Code $\S \S$ 19-3801 to -3804 (1947); Iowa Code ANN. $\$ 751.30$ (1950); Neb. Rev. STat. $\$ 29.820$ (1965); Nev. ReV. Stat. \$\$ 179.125-.155 (1973); N.Y. PENAL LAW \$ 450.10 (McKinney Supp. 1975); N.D. CENTURY CODE $\$ \S 29-01-20$ to -23 (1974); OKLA. STAT. ANN. tit. 22, §§ 1321-1324 (1958); OrE. Rev. Stat. \$§ 142.010-.030 (1974); P.R. LAWS ANN. tit. 34, Appendix II, Rule 251 (1971); S.D. COMPILED LAwS ANN. $\$ \$ 23-16-2$ to -3 (1969); TEX. CODE CRIM. Pro. art. 47.04 (1966); UTAH CODE ANN. \$§ 77-55-1 to -4 (1953); and V.I. CODE ANN. tit. 5, $\S \S 3941-43$ (1967). Fourteen jurisdictions simply require that a claim of ownership be made to the police. ALA. CODE tit. 37, § 490(1.) (1958); Del. Code ANN. tit. 11, \$8307 (1975); Hawair Rev. STAT. $\$ 52-11$ (1968); Ill. ANN. STAT. ch. 141, \$\$ 141-45 (Smith-Hurd 1964), as anended, (Smith-Hurd Supp. 1975); IND. Code § 18-1-11-15 (1974); KAN. STAT. ANN. \$§ 13-14a02, 14-10a02 (1975); MD. ANN. CODE art. 88B, \& 27 (1969); Mich. CoMp. LAwS ANN. \$ 434.171 (1967); N.J. Stat. ANN. \& 40A:14-157 (1975); N.C. Gen. Stat. \& 15-12 (1975); OHo Rev. Code ANN. $\$ 737.29$ (Page 1954); S.C. COde ANN. \$ 57-245 (1962); TENN. Code ANN. § 8828 (1973); and WYo. STAT. ANN. \& 7-2 (1959). Two states provide for application to some body other than the police department. MAss. GrN. LAWS ANN. ch. 92, §89 (1969) (Police Commission); and MinN. STAT. ANN. \$299C.07 (1972) (Bureau of Criminal Apprehension). Finally three states simply require that stolen property be restored to its owner. Colo. Rev. Stat. ANN. \& 18-4-40S (1973); VT. STAT. ANN. tit. $13, \S 2506$ (1974); and WASH. Rev. CODE ANN. \$ 10.79 .050 (1961).

9. Cal. Penal Code $\$ 1407$ (West 1970), as amended, Cal. Penal Code $\$ 1407$ (West Supp. 1976). Section 1407 formerly provided:

When property, alleged to have been stolen or embezzled, comes into the custody of a peace-officer, he must hold it subject to the order of the magistrate authorized by the next section to direct the disposal thereof.

10. Cal. Penal Code $\$ 1536$ (West 1970). 
for returning stolen property to its owner when taken pursuant to a search warrant, ${ }^{11}$ section 1539 affords the owner a possible remedy, providing inter alia:

[I] the grounds on which the warrant was issued be controverted and a motion to return property be made . . . by a person who is not a defendant in a criminal action at the time the hearing is held, the judge or magistrate must proceed to take testimony in relation thereto ....12

If evidence at the subsequent hearing shows that the property taken was not that described in the search warrant, or that there was not probable cause for the warrant to issue, the court must order the return of the property to its rightful owner. ${ }^{13}$ This section is of limited utility, however, because it imposes a heavy burden on the owner to investigate the facts of the seizure in order to contest the seizure's validity. ${ }^{14}$

Section 1407 allows allegedly stolen property seized by a peace officer without a search warrant to be held subject to a court order. ${ }^{15}$ Both under these circumstances, and where the property is held under section 1536, the legal owner may find rehef under sections 1408 to 1410 , which allow the court to control the disposition of stolen property prior to its admission into evidence at trial. ${ }^{16}$ The owner must apply

11. But cf. Buker v. Superior Court, 25 Cal. App. 3d 1085, 102 Cal. Rptr. 494 (4tb Dist. 1972) (holding that under section 1536, and the court's inherent power to prevent abuse of its process, the court can dispose of property seized pursuant to a search warrant).

12. Cal. Penal Code $\$ 1539$ (West 1970).

13. Cal. Penal Code $\$ 1540$ (West 1970).

14. A person not namcd as a defendant but asserting ownership of the property seized pursuant to a search warrant must successfully contest the validity of the seizure before the property can be restored to him. See 52 Or. Cal. ATT'Y GEN. 197, 198 (1969).

15. Cal. Penal Code $\$ 1407$ (West 1970), as amended, Cal. Penal Code $\$ 1407$ (West Supp. 1976). The requireinent of this section extends to all forms of stolen property: see, e.g., People v. Rogers, 241 Cal. App. 2d 384, 390, 50 Cal. Rptr. 559, 562 (2d Dist. 1966) (door keys); People v. Gilliam, 41 Cal. App. 3d 181, 189, 116 Cal. Rptr. 317, 322 (1st Dist. 1974) (credit cards); Cal. Penal CoDe $\$$ 537e(b) (West Supp. 1976) (items with altered manufacturer's serial numbers or identifying marks). The lack of understanding by law enforcement authorities of section 1407's scope is reflected by the fact that the former District Attorney of Los Angeles County considered sections 1407-10 to apply only to cash. Interview with the late Josepl P. Busch Jr., District Attorney of Los Angeles County, in Los Angeles, Feb. 12, 1975, on file at the California Law Review.

16. Cal. Penal Code $\S \S 1408-10$ (West Supp. 1976). Section 1408 provides:

On the application of the owner and on satisfactory proof of his ownership of the property, after reasonable notice and opportunity to be heard has been given to the person from whom custody of the property was taken and any other person as required by the magistrate, the magistrate before whom the complaiut is laid, or who examines the charge against the person accused of stealing or embezzling it, shall order it to be delivered, without prejudice to the state, to the owner....

The provisions of sections 1409 and 1410 are basically similar to those of 1408 , with 
to the court having jurisdiction over the case, show proof of ownership, and notify the defendant and any other interested party as required by the court. The court inay then return the property to its owner. While this statutory scheme appears to provide a workable procedure for the return of stolen property, the infrequency with which its provisions have been used suggests that the remedy is inadequate. ${ }^{17}$

\section{B. Stolen Property Admitted into Evidence}

The disposition of property admitted into evidence at trial is governed by sections 1417 to $1419 .^{18}$ Section 1418 , which controls the return of tangible property to its owner, provides that the trial court "may on application of the party entitled thereto" order the release of any exhibit after the final determination of the action. ${ }^{18}$ If a criminal conviction results and is appealed or if the death sentence is imposed, section 1418 further requires that dehvery await the determination of the appeal or the execution of the death sentence.

Originally, section 1418 was interpreted to be permissive rather than mandatory. ${ }^{20}$ This meant that a theft victim had no absolute right to recover stolen property once it had been introduced into evidence. This curious circumstance caused later courts to hold that the owner of stolen property admitted into evidence had a statutory right to have it returned, at least once the criminal prosecution had ended. ${ }^{21}$

Yet property is often needed by its owner between the time of its introduction into evidence and the final determination of a criminal case. Recognizing this need, the California legislature last year adopted section 1418.6.22 This section provides that a court nnay order any exhibit returned to its owner prior to final determination of the action so long as neither the state nor the defendant is prejudiced and a full and complete photographic record is made of the material released. This statute gives a trial court the sarne control over property admitted into evidence that it has over property prior to its introduction under sections 1408 to 1410 . Section 1418.6 adds hittle practical value, however, because, like sections 1408 to 1410 , it does not reheve

section 1409 controlling at the preliminary hearing stage of a criminal prosecution, and section 1410 controlling at trial before the property' is actually admitted into evidence.

17. From Jan. 1, 1975, to Aug. 15, 1975, the provisions of sections 1408-1410 were utilized by victims only twice in Alameda County. Janssen Interview, supra note 2.

18. Cal. Penal Code $\$ \$ 1417-19$ (West 1970, Supp. 1976).

19. Cal. Penal Code $\$ 1418$ (West Supp. 1976) (emphasis added). 1966).

20. People v. Tuttle, 242 Cal. App. 2d 883, 884, 52 Cal. Rptr. 204, 206 (4th Dist.

21. E.g., Espinosa v. Superior Court, 50 Cal. App. 3d 347, 123 Cal. Rptr. 448 (3d Dist. 1975); Franklin v. Municipal Court, 26 Cal. App. 3d 884, 103 Cal. Rptr. 354 (1st Dist. 1972).

22. Cal. Penal Code $\S 1418.6$ (West Supp. 1976). 
the property owner's burden of applying to the court for release prior to final determination of the action.

\section{The New Statutory Scheme}

The California legislature in 1975 expanded the property return scheme by amending section 1413 to provide an alternative inethod for returning property not yet admitted imto evidence. The procedural requirements of section 1413 are as follows: First, the owner inust place a claim for the property with the local police department's property clerk and present proper personal identification and satisfactory proof of ownership. Second, the person from whom the property was taken must receive notice of the ownership claim and a copy of any proof of ownership tendered, and must be given an opportunity to contest the claim of ownership. Third, a complete photographic record of the itein must be made. Fourth, upon receipt of the property the claimant must sign a declaration of ownership under penalty of perjury. Finally, the court having jurisdiction over the criminal case must immediately review the decision of the police clerk if the defendant objects to the property's restoration. ${ }^{23}$ Special guidelines govern the return of stolen property which has an altered manufacturer's identification number. ${ }^{24}$

The most significant effect of the statute is that it substitutes administrative determination for court-ordered disposition of property. This system obviates the need to retain counsel to recover a stolen item, ${ }^{25}$ to request the prosecuting attorney to apply for restoration of the property, or to appear personally before the court. Moreover, since the property can be claimed at any time after it comes into police custody, the period during which the owner is deprived of its use and possession can be greatly reduced.

\section{II}

\section{Operational Considerations}

Section 1413 presents a number of operational problems which must be resolved: the implementation of administrative procedures;

23. Cal. Penal Code $\$ 1413$ (West Supp. 1976).

24. Cal. Penal Code $§ 1413$ (a) (West Supp. 1976). The property clerk is authorized to imbed a new identification number in the property. The statute does not specify that the new number must be assigned by the manufacturer. Practically, this is not possible. To avoid the possibility of having duplicate numbers assigned to fungible items by different police agencies, each department should use a consistent numbering system in conjunction with a logo standing for the police department. For example, the symbol 7600090AKPD would identify the nimth item with a defaced identification number returned to its owner in 1976 by the Oakland Police Department.

25. In most cases where a private citizen's property is stolen, the market value of the item does not warrant the retention of counsel. Janssen Interview, supra note 2. 
the binding force of administrative determinations of property interests; administrative impartiality; the protection of additional claimants; and the evidentiary needs of the prosecution and the defense.

\section{A. Establishing the Administrative Process}

By giving the person from whom custody of the property was taken an opportunity to dispute any claim of ownership to the property, section 1413 impliedly establishes a police administrative hearing. ${ }^{20}$ However, the implementation of the statute is not mandatory. ${ }^{27}$ Should the administrative process prove cumbersome, pohice departments may decide not to implement the statute. Since any hearing procedure is arguably cumbersome, police departments can be expected to estabhsh the least unwieldy system possible. The problem is that, because the hearing and notice requirements are imprecisely stated in section $1413,{ }^{28}$ law enforcement agencies nay establish informal proeedures which are legally questionable. ${ }^{29}$ Police departments should be urged to establish formal procedures which are legally and constitutionally sufficient. $^{30}$ Formal procedures may prove to be relatively cumbersoine, ${ }^{31}$ but section 1413 was designed in part to legitimate in a consti-

26. See Memorandum from Joe Busch to Howard Janssen, May 27, 1975, on file at the California Law Review.

27. Cal. Penal Code $\S 1413$ (b) (West Supp. 1976). See also Memorandum from Howard Janssen and Joe Busch to Dick Iglehart, supra note 8.

28. Section 1413(b) should be amended to reflect the more formal procedural requirements found in District of Columbia Code section 4-156(b): conditions mandating a hearing should be defined; the property clerk should be empowered to hear and receive evidence about the property at a hearing where all interested parties may be present; and the form of notice required should be specified.

29. See Fremont Police Dep'r, Operations Directive: Property ProcessIng/Processing of Property, Sept. 30, 1975, on file at the California Law Review. Although this directive was issued before the present version of section 1413 went into effect, its promulgation was prompted by the fact that the legislation amending section 1413 had already been signed by the governor. The directive's major defect is that it provides no notice to the person from whom custody of the property was taken.

30. This could most simply be accomplished by interpreting the statute strictly by: (1) requiring the claimant to fill out an application of ownership, (2) giving written notice to the defendant, ( 3 ) conducting a learing a few days after the initial application at which both the claimant and the defendant may be present, and (4) establishing guidelines for the hearing clerk as to what constitutes satisfactory proof of ownership and what evidentiary needs of the defense will outweigh the needs of the claimant to have the property restored.

Even though section 1413(b) fails to specify what form notice should take, written notice is recommended as that form most reasonably calculated under all the circumstances to apprise the defendant of the pendency of the hearing and to afford him an opportunity to present his objections. See Mullane v. Central Hanover Bank \& Trust Co., 339 U.S. 306, 314 (1950). If the defendant is in custody, notice inust be sent to the place of detention and not merely to a prior residence. Robinson v. Hanrahan, 409 U.S. 38, 40 (1972). See also Hill v. Gold, 79 Misc. 2d 1055, 1057, 362 N.Y.S.2d 328, 332 (Sup. Ct. 1974).

31. Such a fornal system is not necessarily too burdensome. The required time 
tutionally sufficient fashion the preexisting illegal practice of certain police departments of restoring stolen property to its owner without court direction or notice to the defendant. ${ }^{32}$ Thus, the police have three choices: to violate the law as has been done by some departments in the past, to refuse to implement section 1413 and continue to bear the storage costs of stolen property, or to implement section 1413 in a legally sufficient manner even though the procedure is mildly burdensome. The last alternative is the only viable choice.

\section{B. Administrative Determination of Property Rights}

The ability of an administrative body to affect interests in property is an issue that has not been decided in California. In returning stolen property under section 1413, a police property clerk necessarily decides certain rights of the parties to that property. The validity of this procedure depends on whether or not the clerk's decision is an impermissible exercise of judicial power.

In California judicial power is vested in the courts of the state, ${ }^{33}$ and an administrative body cannot exercise such power. ${ }^{34}$ Courts have defined judicial power as the authority to adjudicate the legal rights concerning persons or property in a manner which nakes the judgment bimding. ${ }^{35}$ By restoring stolen property to its owner under the provisions of section 1413, the clerk does decide the issue of ownership, but the decision is binding only in the sense that the claimant has possession of the property. The clerk's decision does not have the full force of a judgment because section 1413(c) specifically empowers the court having jurisdiction over the criminal case to review de novo the question of ownership on the application of the party aggrieved by the property clerk's decision. ${ }^{36}$

expenditure is not much greater than where property is illegally returned to its owner. Additional paperwork is imvolved but this can be minimized by using standardized forms for application of ownership and written notice. Fimally, locating the defendant should not prove difficult because the face sheet of most police reports contains information as to the defendant's residence.

32. See Memorandum from Howard Janssen and Joe Busch to Dick Iglehart, supra note 8. See also interview with Joseph $\mathrm{P}$. Busch, $\mathrm{J}_{\mathrm{r}}$, supra note 15 . Such conduct by the police, besides being in violation of state law, is also in violation of a defendant's due process rights in the stolen property. People v. Lawrence, 140 Cal. App. 2d 133, 295 P.2d 4 (1st Dist. 1956); Modern Loan Co. v. Police Court, 12 Cal. App. 582, 108 P. 56 (2d Dist. 1910); cf. MceClendon v. Rosetti, 460 F.2d 111 (2d Cir. 1972).

33. CAL. CONST. art. $6, \S 1$. Judicial power is also vested in the state sentate when it sits as a court of impeachment.

34. Tamble v. Downey, 104 Cal. App. 2d 810, 811, 232 P.2d 543, 544 (1st Dist. 1951).

35. E.g., Fewel v. Fewel, 23 Cal. 2d 431, 435, 144 P.2d 592, 594 (1943); People v. Bird, 212 Cal. 632, 640-41, 300 P. 23, 26 (1931).

36. Cal. Penal Code \& 1413(c) (West Supp. 1976). 
The effect of a provision for a de novo judicial hearing after an administrative decision was presented to the California Supreme Court in Garson v. Division of Labor Law Enforcement. ${ }^{37}$ There the court considered the validity of Labor Code provisions giving the labor commissioner power to settle certain contract disputes between employment agencies and their clients. ${ }^{38}$ The supreme court held that the commissioner's authority was valid because the statute also provided for review by de novo judicial hearing. ${ }^{39}$ The court suggested that the availability of such a hearing precluded any decision by the commissioner froin having the binding force of a legal judgment. The same reasoning prevents section 1413 from having the binding force of a legal judgment and upholds the validity of the administrative procedure. $^{40}$

\section{The Requirement of Impartiality}

Any hearing conducted by an administrative body must be fair and impartial. ${ }^{41}$ Arbitrary or capricious exercise of admimistrative powers is a ground for setting aside any administrative decision. ${ }^{42}$ Provisions in section 1413 for notice and hearing for the defendant, coupled with the requirements of proof by the claimant, go far toward ensuring impartiality. ${ }^{43}$ Yet the question remains whether a police property clerk is a proper administrative officer to conduct the hearing, since the clerk - who is an employee of the police department-arguably is not sufficiently disinterested to be impartial. Califorma courts, however, have not equated fairness with disinterest. Many state agencies have been allowed to hold administrative hearings to decide issues in which they

37. 33 Cal. 2d 861, 206 P.2d 368 (1949).

38. Ch. 90, §§ 1626, 1647 [1937] Cal. Stat. 236, 240 (repealed 1967).

39. $33 \mathrm{Cal} .2 \mathrm{~d}$ at 864,206 P.2d at 370 .

40. Accord, Carroll v. E. Heidenheimer, Inc., 44 A.2d 71 (D.C. Mun. App. 1945). In Carroll, the court upheld the validity of that jurisdiction's property return statute despite the property clerk's ability to deliver possession of allegedly stolen property to one of two or more claimants, because there was an implied right to a de novo hearing in the municipal court. Id. at 72. More importantly, the court also held that, because a de novo judicial hearing was available, the clerk's determination did not have the force of a judgment. Id. The court felt that it did not bave to reach the question of whether the property clerk exercised judicial power because of the right to a de novo judicial determination of ownership. Id. See also Lewis v. Aderholdt, 203 A.2d 919, 923 (D.C. App. 1964), cert. denied, 382 U.S. 872 (1965).

41. E.g., Alta-Dena Dairy v. County of San Diego, 271 Cal. App. 2d 66, 77, 76 Cal. Rptr. 510, 518 (4th Dist. 1969).

42. Gonsalves v. City of Dairy Valley, 265 Cal. App. 2d 400, 404, 71 Cal. Rptr. 255, 258 (2d Dist. 1968).

43. See Stewart v. County of San Mateo, 246 Cal. App. 2d 273, 285, 54 Cal. Rptr. 599, 606 (1st Dist. 1966) (upholding a local ordinance establishing notice and hearing procedures for the revocation of licenses for private investigators). 
were interested. ${ }^{44}$ Therefore, the question of impartiality does not depend upon the employer of the person conducting the administrative hearing, but rather on the official's good faith compliance with the statutory procedures established. ${ }^{45}$

\section{Protection of Additional Claimants}

Section 1413(b) requires that notice be given only to the person from whom custody of the property was taken $;^{46}$ no provision is made for notice to others who may have an interest in the property. ${ }^{47}$ The statute does provide, however, that any delivery of stolen property to its owner shall be without prejudice to the rights of any other person who may have a claim against the property. ${ }^{48}$ Nonetheless, this provision does not protect any additional claimant froni continued denial of the use of the property. ${ }^{48}$ It does, however, protect the interests of a defendant who, if acquitted and shown to be the actual owner of the property, can compel dehivery of the property from the alleged victim under section 1413(c)..$^{50}$

A related problem arises where allegedly stolen property is recovered by the police but the defendant has not been arrested. Section 1413(b) requires that notice be given to the "person from whom custody of the property was taken." 51 In most imstances that person will be the defendant. A person suspected of having committed a theft;

44. See, e.g., Rios v. Cozens, 7 Cal. 3d 792, 103 Cal. Rptr. 299, 499 P.2d 979 (1972) (Dep't of Motor Vehicles hearings to revoke drivers' licenses); In re Petersen, 51 Cal. 2d 177, 331 P.2d 24 (1958) (local police control of taxicab permits); Gore v. Harris, 229 Cal. App. 2d 821, 40 Cal. Rptr. 666 (1st Dist. 1964) (Dep't of Alcoholic Beverage Control suspension of business liquor licenses).

45. See Saks \& Co. v. City of Beverly Hills, 107 Cal. App. 2d 260, 265, 237 P.2d 32,36 (2d Dist. 1951). A property clerk is liable for any damages that arise out of a decision to return stolen property unless the clerk has acted in good faith. CaL. Penal CODE $\$ 1413$ (e) (West Supp. 1976).

46. Cal. Penal Code $\$ 1413$ (b) (West Supp. 1976).

47. Additional claimants might include: an insurer if the goods stolen were insured and a claim was made by the owner; secured creditors who have levied on the property through the sheriff; a warehouse company which was storing the goods for the owner when they were stolen and which has reimbursed the owner for the loss; and bona fide purchasers of the property from the thief who never made delivery of the property.

48. Cal. Penal Code $\$ 1413$ (b) (West Supp. 1976).

49. The fact that the clerk conducting the hearing might give notice to a party not specified in the statute is irrelevant since the statute itself does not require that such notice be given. Matter of Lambert, 134 Cal. 626, 634, 66 P. 851, 854 (1901); People v. Lawrence, 140 Cal. App. 2d 133, 136, 295 P.2d 4, 7 (1st Dist. 1956); Modern Loan Co. v. Police Court, 12 Cal. App. 582, 586, 108 P. 56, 58 (2d Dist. 1910).

Where the police property clerk has knowledge of another claim or where he does not understand the nature of the claim presented, such as that of a secured creditor, the clerk should decline to restore the property and inform all claimants of the availability of relief under sections 1408 to 1410 .

50. Cal. Penal Code $§ 1413$ (c) (West Supp. 1976).

51. Cal. Penal Code $\$ 1413$ (b) (West Supp. 1976). 
and having an outstanding arrest warrant, is unlikely to appear at a police administrative hearing, even if notice could be given. The statute should be clarified to protect the property claimant where it is not possible to give the suspect notice of the administrative hearing. Where the suspect receives notice but does not appear, the claimant should be awarded the property subject to a later action by the suspect.

\section{E. Evidentiary Need's}

Restoring stolen property to its owner prior to trial may pose evidentiary problems where the property is crucial to the prosecution or the defense. ${ }^{52}$ Because the statute's provisions are permissive, ${ }^{53}$ the property clerk need not release the property to its owner if there is a special evidentiary need for it. To ensure protection of such evidence, the prosecution or defense counsel will have to examine the facts of the case at an early stage of the criminal proceedings; but it is not inappropriate to place the burden of demonstrating the need for retaining property on those who may later use the property at trial.

Special evidentiary needs are served by the provision for a complete photographic record of property released. ${ }^{54}$ This procedure enables photographs to be placed into evidence in heu of the property itself. ${ }^{55}$ If the photographs are not sufficient, either the prosecution or the defense can have the property brought into court by means of a subpoena duces tecum. To prevent problems which could arise if the property were disposed of prior to trial, ${ }^{58}$ the owner should not be able to dispose of it until after the termination of the criminal prosecution. ${ }^{57}$ Since the claimant secures the return of his property without

52. In all cases alleging theft, the property is crucial in the sense that it is the corpus delicti of the crime. As used here, the term crucial means there is evidence on the property itself directly linking it to the defendant, such as fingerprints or shreds of clothing, which requires that it be submitted to criminalistics tests prior to its return to the owner.

53. Cal. Penal Code $\S 1413$ (b) (West Supp. 1976).

54. Id.

55. See Meinorandum from Howard Janssen and Joe Busch to Dick Iglehart, supra note 8. The admissibility of photographs into evidence and the problems associated therein are discussed in B. WITKIn, California Evidence $\$$ 635-638 (2d ed. 1966).

56. This problem was a special concern of Committee Counsel for the California Assembly Conmittee on Criminal Justice. See Assembly Comm. on Criminal Justice, Bull Digest: Senate Bill 1212, at 3, Aug. 20, 1975, on file at the California Law Review.

57. The property clerk should always inform the owner that the return is without prejudice to the state or the defense and that no attempt should be made to dispose of the property prior to the end of the trial. An appropriate amendment to the statute might be a prohibition on selling or otherwise knowingly disposing of nonperishable stolen property prior to the determination of the trial. "Perishable goods" should be defined broadly to include any item returned to a merchant which is commonly sold by that 
prejudice to the state or to the defense, ${ }^{58}$ rights in the property should necessarily extend only to its use and possession. In the event that the property is inadvertently destroyed, the photographs would presumably have to suffice as evidence.

\section{III \\ Constitutional Considerations}

Because the restoration of stolen property to its owner will in most cases be related to a criminal prosecution, any return procedure inust conform to the constitutional protections afforded the criminal defendant.

\section{A. The Privilege Against Self-Incrimination}

It is unclear under the California statute whether a defendant can assert an interest in property subject to the section 1413 procedure without waiving the fifth amendment privilege against self-incrimination. The Umited States Supreme Court in Simmons v. United States ${ }^{58}$ held that a defendant at a hearing to suppress evidence cannot be forced to choose between asserting the fifth ainendment right to remain silent and the fourth amendment right to be free from unlawful seizures. ${ }^{60}$ In United States v. Harrison, ${ }^{61}$ the Fifth Circuit construed Simmons to inean that any statement made by a defendant when forced to choose between fifth amendment rights and any other constitutional rights (here, fourteenth amendment rights) was to be excluded from evidence. $^{62}$ A hearing to return stolen property might force defendants to choose between asserting their fifth amendment rights and their fourteenth amendment interests in the property. ${ }^{63}$ Originally, the drafters of section 1413 thought that the reasoning in Harrison would control any hearing where interests in stolen property are decided. ${ }^{64}$ The subsequent decision by the California Supreme Court in People

merchant. Such a definition would avoid requiring merchants to retain commercial goods which are subject to seasonal or "stylistic" obsolescence.

58. Cal. Penal Code $§ 1413$ (b) (West Supp. 1976).

59. 390 U.S. 377 (1968).

60. Id. at 394.

61. 461 F.2d 1127 (5th Cir. 1972).

62. Id. at $1132 \mathrm{n} .11$.

63. In Cahfornia a defendant is decmed to have a sufficient ownership interest in stolen property to be afforded fourteenth amendment protections. People v. Lawrence, 140 Cal. App. 2d 133, 295 P.2d 4 (1st Dist. 1956); Modern Loan Co. v. Police Court, 12 Cal. App. 582, 108 P. 56 (2d Dist. 1910). See also People v. Hopkins, 44 Cal. App. 3d 326, 329, 118 Cal. Rptr. 683, 684 (2d Dist. 1975).

64. See Memorandum from Joe Busch to Howard Janssen, March 15, 1975, on file at the California Law Review. 
v. Coleman $^{65}$ indicates, however, that the reliance on Harrison's interpretation of Simmons may have been misplaced.

In Coleman the court considered whether the statements of a defendant at a probation revocation hearing were admissible in the prosecution of the charge itself. In rejecting the defendant's constitutional arguinent based on Simmons, the court found that the federal law on the question was "in a state of confusion." ${ }^{6}$ The "confusion" stems from the nore recent decision of the United States Supreine Court in McGautha v. California. ${ }^{67}$ One of the issues confronting the Court in McGautha was whether a state could have a single trial on the issues of guilt and punishment, thus forcing the defeudant to choose between remaining silent on the issue of guilt at the cost of surrendering the clance to plead inost effectively on the issue of punishment. ${ }^{08}$ The Court did not take the approach the Fifth Circuit took in Harrison; rather, it confined the application of Simmons to its facts, a conflict between assertion of fourth and fifth amendment rights, ${ }^{\circ 0}$ and opeuly questioned the validity of the reasoning used in Simmons. ${ }^{70}$ Consequently, it is uncertam whether a defendant could constitutionally prevent the use at trial of statements inade at any hearing other than a suppression hearing.

As a inatter of California law, however, a defendant may be able to suppress any statements made at a section 1413(b) hearing. While the California Supreme Court did not apply the Simmons rationale in Coleman, it did suppress the statements of the defendant at the probation revocation hearing in the interests of the fair administration of justice. $^{71}$ The court did so because it found that the use of the prior stateinents violated two of the policies underlying the privilege agamst selfincrimination: maintaining a fair state-individual balance at the subsequent criminal trial and preventing placing the accused in the dilemma of clioosing either self-incrimination or perjury. ${ }^{72}$ Both of these policies would be violated by allowing the use in a criminal prosecution of a defendant's statements made at a section 1413(b) hearing.

65. 13 Cal. 3d 867, 120 Cal. Rptr. 384, 533 P.2d 102.4 (1975).

66. Id. at 878, 120 Cal. Rptr. at 394, 533.P.2d at 1034 .

67. 402 U.S. 183 (1971).

68. Id. at 211. The challenge to the unitary trial system was raised in a companion case, Crampton v. Ohio, which the Supreme Court consolidated with McGautha.

69. Id. at 212 .

70. Id. at 212-13.

71. $13 \mathrm{Cal}$. 3d at 888, $120 \mathrm{Cal}$. Rptr. at 401, 533 P.2d at 1041. For a discussion of the possible impact of Coleman, see Note, Use of Probation Revocation Hearing in Subsequent Criminal Trials, 64 CALIF. L. REv. 516 (1976).

72. 13 Cal. 3d at 875, 878, 120 Cal. Rptr. at 392, 394, 533 P.2d at 1032, 1034. 
Return of stolen property under section 1413 will more often be made prior to trial. Thus, any statement made by the defendant at the hearing would be available for use at trial. The property return hearing may be viewed as an attempt to "trick" a confession out of the defendant, who may very well choose not to participate even where there is a legitimate imterest to assert. If the defendant does decide to speak and if the property is in fact stolen, the defendant must choose between lying to assert an ownership interest in the property and selfincrimination by denying ownership. A defendant under the misapprehension that silence in the face of a claim will be viewed in a later trial as a tacit admission of guilt might decide to he to avoid such a conclusion. Given the policy considerations of Coleman and the intent of the authors of section 1413, a California court should require the exclusion of any statements a defendant makes at an administrative hearing held under section $1413(b) .^{73}$

\section{B. The Right to Counsel}

The sixth amendment requires that counsel be allowed to be present at every stage of a criminal proceeding where substantial rights of the defendant may be affected. ${ }^{74}$ The subject of a section 1413(b) hearing is the disposal of stolen property, and not the resolution of questions affecting the defendant's hiberty. As such, the hearing is not part of a prosecutorial process in which the power of the state is brought to bear against the defendant, but is a simplified proceeding similar to a civil action. Thus, a hearing conducted under section 1413 (b) should not require the presence of counsel to protect the defendant's sixth amendment rights.

Yet, as the Supreme Court observed in United States v. Ash, ${ }^{75}$ the need for counsel is to be tested by an examination of the event "in order to determine whether the accused required aid in coping with legal problems or assistance in meeting his adversary."78 If a defendant's statements at the property return hearing could be used at the ensuing trial, the perceived compulsion to speak coupled with the possibility that the defendant might make an incriminating statement be-

73. To ensure this result, section 1413 (b) should be amended to require the exclusion of any statement made by a defendant at a hearing to return stolen property, except for purposes of impeachment. Even a statement made at a suppression hearing may be used to impeach a defendant at trial. See People v. Sturgis, 58 III. 2d 211, 317 N.E.2d 545 (1974), cert. denied, 420 U.S. 936 (1975).

74. See, e.g., Mempa v. Rhay, 389 U.S. 128 (1967).

75. 413 U.S. 300 (1973).

76. Id. at 313. In a concurring opinion, Justice Stewart suggested an alternative test: whether counsel is required to preserve the defendant's right to effective crossexamimation. Id. at 325. 
fore an employee of the police department may require the presence of counsel. ${ }^{77}$

Nonconstitutional considerations might also necessitate allowing counsel to appear at the section 1413 (b) learing. ${ }^{78}$ The statute requires that the defendant be given an opportunity to contest delivery of stolen property to the clainant. ${ }^{70}$ If the defendant cannot assert a property interest, ${ }^{80}$ for whatever reason, the attorney should be allowed to do so. Furthermore, the property return hearing inay be the defense counsel's only chance to observe certain stolen property while it is still in the custody of state authorities. . $^{81}$

\section{Due Process}

The fourteenth amendment protects interests in property. ${ }^{82}$ Thus, before an individual can be deprived of any significant interest in property, due process requires notice and an opportunity for a hearing. ${ }^{83}$

77. This underscores the need to exclude from trial any statements made by a defendant at a property return hearing. Of course, the defendant could remain silent or fail to appear. Yet, it would hardly seem fair to allow the prosecution to admit into evidence the fact that a hearing was conducted to determine the ownership of the stolen property and that the defendant, with notice of the hearing, failed to appear. Clearly, evidence of failure to appear at the hearing to determine ownership of stolen property should not be used at trial against the person from whon custody of the property was taken.

78. There is nothing in the statute which prevents a defendant from having counsel present at a section 1413 hearing. But since the statute only provides that the defendant be given an opportunity to be heard, it is unclear whether counsel can appear if the defendant does not. An amendment to section 1413 to allow the defendant's representative to be present in lieu of the defendant would resolve most of the problems presented herein.

The presence of defense counsel arguably will impose a similar burden on the victim to have counsel present and thus defeat one of the central purposes of section 1413. But given the informal nature of the hearing and since formal rules of evidence would not necessarily apply, there seems to be no distinct advantage in refaining counsel. Additionally, if a defendant's failure to assert an ownership interest in the property cannot be introduced at the later trial, in most cases the claim would probably go uncontested.

79. Cal. Penal Code $§ 1413$ (b) (West Supp. 1976).

80. Reasons for a failure to appear at a property return hearing could include plysical incapacity or the fact that the defendant is in the custody of some other jurisdiction or law enforcement agency.

81. A defendant is not entitled as a matter of: right to inspect material evidence held by the police without a prior showing of good cause. Hill v. Superior Court, 10 Cal. 3d 812, 817, 112 Cal. Rptr. 257, 260, 518 P.2d 1353, 1356 (1974). However, the prosecution must disclose any evidence which it has and which is favorable to the accnsed. In re Ferguson, 5 Cal. 3d 525, 532, 96 Cal. Rjtr. 594, 599, 487 P.2d 1234, 1239 (1971).

82. Lynch v. Household Finance Corp., 405 U.S. 538, 544 (1972).

83. Fuentes v. Shevin, 407 U.S. 67 (1972); Sniadach v. Family Finance Corp., 395 U.S. 337 (1969); Randone v. Appellate Dep't, 5 Cal. 3d 536, 96 Cal. Rptr. 709, 488 P.2d 13 (1971). If a deprivation of property is authorized by statute, the statute itself must provide for notice and a liearing. People v. Amor, 12 Cal. 3d 20, 29, 114 Cal. Rptr. 
California appellate courts have twice held that a criminal defendant has sufficient interests in stolen property to require the protections of the fourteenth amendinent. ${ }^{84}$

Section 1413 provides for notice to the person from whoin custody of the property was taken and an opportunity to be heard before a police property clerk to show why the property should not be released to the claimant. ${ }^{85}$ The unresolved question is whether the hearing provided is sufficient to meet the requirements of due process. Recent Supreine Court decisions regarding garnishment and replevin statutes are instructive in the resolution of this issue.

In Fuentes $v$. Shevin ${ }^{86}$ the Court considered the validity of the Florida and Pennsylvania replevin statutes. The Court held that the statutes were unconstitutional because they lacked the due process requirements of notice and a judicial hearing for the possessor before the deprivation took place. ${ }^{87}$ This does not inean that a hearing must be held before a judicial body in all cases where a property interest is affected. As the Court observed, a variance in the form of a hearing can be tolerated in appropriate instances depending upon the nature of the case, the importance of the interests involved, and the nature of any subsequent proceedings, so long as the opportunity for that hear-

765, 770, 523 P.2d 1173, 1178 (1974); Matter of Lambert, 134 Cal. 626, 634, 66 P. 851, 854 (1901).

84. People v. Lawrence, 140 Cal. App. 2d 133, 295 P.2d 4 (1st Dist. 1956); Modern Loan Co. v. Police Court, 12 Cal. App. 582, 108 P. 56 (2d Dist. 1910). In Lawrence the eourt held that stolen property presumptively belongs to the defendant and that notice and a hearing were required before the defendant could be deprived of that interest. 140 Cal. App. 2d at 137-38, 295 P.2d at 7-8. In Modern Loan the court based its decision on the fact that the petitioner had possession of the stolen property prior to a search warrant being executed. The court reasoned that a party could not be deprived of possession of property without reasonable notice and an opportunity to be heard. 12 Cal. App. at 587, 108 P. at 58.

On a related question, the Court of Appeals for the Second Circuit held that a defendant acquitted on a charge of theft has interests in the allegedly stolen property which are protected by the fifth and fourteenth amendments. McClendon v. Rosetti, 460 F.2d 111, 116 (2d Cir. 1972). See also Menkarell v. Bureau of Narcotics, 463 F.2d 88, 95 (3d Cir. 1972); Stuyvesant Ins. Co. v. Department of Treasury, 378 F. Supp. 7, 13 (S.D.N.Y. 1974).

Given the findings of the California Court of Appeal and the Second Circuit, the validity of the property return statutes in those 36 jurisdictions which do not afford nutice to the criminal defendant is questionable. See note 8 supra.

85. Cal. Penal Code $\$ 1413$ (b) (West Supp. 1976).

86. 407 U.S. 67 (1972). The statutes considered by the Court allowed a secured creditor to obtain an ex parte writ of replevin for the seizure of specific property allegedly wrongfully detained. While the creditor had to post bond before the writ issued, the possessor of the property was not allowed to eontest the attachment until several days after the seizure and only after posting a security bond of double the value of the property seized. Id. at 84 .

87. Id. at 80. 
ing is provided before a deprivation of property interests can take place. ${ }^{88}$

Although a prior hearing of some form was mandated in Fuentes before a deprivation of property interests could occur, in Mitchell $v$. W.T. Grant Co. $^{89}$ the Court appeared to withdraw from that requirement. In upholding Louisiana's sequestration statute, ${ }^{90}$ the Court characterized the Fuentes decision as

... merely stand[ing] for the proposition that a hearing must be had before one is finally deprived of his property and do[es] not deal at all with the need for a pretermination hearing where a full and immediate post-termination hearing is provided. ${ }^{01}$

The Court reasoned that, where only proprietary interests are involved, due process is satisfied if there is an adequate opportunity for a swift judicial determination of the controversy. ${ }^{92}$ Thus, under Mitchell, due process for property interests depends not on whether there was a predeprivation hearing but on whether there was full and immediate judicial control after the deprivation had taken place.

While soine courts viewed the decision in Mitchell as a significant withdrawal from the due process requirements detailed in Fuentes, ${ }^{93}$ the Court evidently believed that Fuentes still had life in it because 9 months after Mitchell it rendered its decision in North Georgia Finishing, Inc. v. Di-Chem, Inc. ${ }^{94}$ In Di-Chem the Court found Fuentes, not Mitchell, to be controlling and invalidated Georgia's garnishment statute. ${ }^{95}$

88. Id. at 82. See also Velazco v. Minter, 481 F.2d 573, 578 n.10 (1st Cir. 1973); Palmer v. Columbia Gas of Ohio, Inc., 479 F.2d 153, 168 (6th Cir. 1973); Skelly v. State Personnel Bd., 15 Cal. 3d 194, 209, 124 Cal. Rptr. 14, 25, 539 P.2d 774, 785 (1975); Beaudreau v. Superior Court, 14 Cal. 3d 448, 458, 121 Cal. Rptr. 585, 591, 535 P.2d 713, 719 (1975).

89. 416 U.S. 600 (1974).

90. The statute provided for ex parte issuance of a writ of sequestration upon the plaintiff's affidavit and for an immediate post-deprivation hearing to enable the defendant to have the writ dissolved. The Court upheld the statute and found it to differ from the Florida statute invalidated in Fuentes in a number of ways: (1) only a judge could issue the writ in Louisiana, whereas a court clerk issued the writ of replevin in Florida; (2) the writ in Louisiana could issue only on a sworn affidavit containing allegations of fact sufficient to prove the plaintiff's right to possession; and (3) the defendant had a right to an immediate post-deprivation hearing to dissolve the writ. Id. at 615-18.

91. Id. at 611 .

92. Id.

93. See, e.g., In re the Oronoka, 393 F. Supp. 1311, 1316 (D. Me. 1975); Phillips v. Bartoloinie, 46 Cal. App. 3d 346, 350 n.3, 121 Cal. Rptr. 56, 59 n.3 (1st Dist. 1975). See also Justice Stewart's dissent in Mitchell v. W.T. Grant Co., 416 U.S. 600, 629 (1974).

94. 419 U.S. 601 (1975).

95. Id. at 605 . While the Court found the decision in Fuentes to be controlling, it struck down Georgia's garnishment statute using the same tests as were applied in Mitchell: (1) the writ issued without judicial control; (2) the affidavit did not require 
The reconciliation of these decisions is difficult.96 The Court seems to be saying that due process is a flexible concept ${ }^{97}$ and that interests must be balanced before the constitutionality of a statute can be determined..$^{98}$ Factors to be considered in the balancing of interests mclude: whether the predeprivation safeguards minimize the risk of error in the initial decision; whether the surrounding circumstances necessitate quick action; whether the interim loss incurred by the person affected is substantial; whether the postdeprivation hearing is sufficiently prompt; and whether the person aggrieved will be entitled to adequate compensation in the event the deprivation of his property interest proves to be wrongful. ${ }^{99}$

Section 1413 appears to survive this balancing test. Initially, the claimant must assert an ownership imterest and not merely a security interest in the allegedly stolen item. The statute minimizes the chance of error at the property clerk's hearing by requiring proof of ownership and by affording notice and a hearing to the person from whom custody of the property was taken. Although the property will still be available after the trial is completed, quick action is nevertheless necessary because the victim of the crime should not be deprived of the use of the property for a prolonged period. ${ }^{100}$ Absent section 1413, the victim's only alternative is to apply to the court having jurisdiction over the criminal case under sections 1408 to 1410 , but the value of the property seldom justifies hiring counsel to make such application. ${ }^{101}$ The

allegations of fact; and (3) there was no provision for an early judicial hearing after deprivation. Id. at 607. See Hansford, Procedural Due Process in the Debtor-Creditor Relationship: The Impact of Di-Chem, 9 GA. L. REv. 589, 605-09 (1975); Note, Constitutional Law-Due Process-Ex Parte Garnishment Statute Held Invalid, 7 ST. MARY's L.J. 423, 431 (1975).

96. Since the Court in Di-Chem did not overrule Mitchell, the result has been confusion among commentators as to the status of the law of creditors remedies. See Hansford, Procedural Due Process in the Debtor-Creditor Relationship: The Impact of Di-Chem, 9 Ga. L. Rev. 589, 605-09 (1975); Comment, A Confusing Course Made More Confusing: The Supreme Court, Due Process, and Summary Creditor Remedies, 70 Nw. U.L. REv. 331 (1975); Note, Constitutional Law_Prejudgment Garnishment, 1975 WIS. L. REV. 860, 873-74.

97. Skelly v. State Personnel Bd., 15 Cal. 3d 194, 209, 124 Cal. Rptr. 14, 24, 539 P.2d 774, 784 (1975).

98. See Guzman v. Western State Bank, 516 F.2d 125, 128 (8th Cir. 1975); Hutchinson v. Bank of N. Carolina, 392 F. Supp. 888, 892 (M.D.N.C. 1975). See also Comment, State Action: A Pathology and a Proposed Cure, 64 CALIF. L. Rev. 146, 17071 (1976); Note, North Georgia Finishing, Inc. v. Di-Chem, Inc.: Prejudgment Due Process Rights Redefined, TEMP. L.Q. 1013, 1020 (1975).

99. Skelly v. State Personnel Bd., 15 Cal. 3d 194, 209, 124 Cal. Rptr. 14, 25, 539 P.2d 774, 785 (1975).

100. Retention of the property by the police may even constitute denial of the victim's due process rights simce there is deprivation of the possession and use of property by the state without notice or an opportunity to be heard.

101. Janssen Interview, supra note 2. 
defendant who has already been legally deprived ${ }^{102}$ of stolen property would not have a counterbalancing interim interest in the property. Additional protection is afforded the defendant by the section 1413(c) right to immediate judicial review of the clerk's decision. ${ }^{103}$ In the event the clerk's decision is reversed upon judicial review, the court will take custody of the property. Because of the nature of the interests involved in stolen property and the sufficiency of the section 1413 procedure, the return of stolen property is an appropriate situation for variance froin the traditional norm in the form of hearing. ${ }^{104}$

\section{IV}

\section{PROPOSED REVISIONS}

The problems associated with section 1413 are due to imprecise language and a lack of foresight as to what was required of the police in implementing it. To remedy the defects previously identified, section 1413 should be amended as follows:

(b)(1) The clerk or person in charge of the property section may, upon satisfactory proof of the ownership of the property held pursuant to Section 1407, [and upon presentation of proper personal idcntification] dehiver it to the owner or his legal representative. ${ }^{105}$ The person to whom property is delivered shall sign, under penalty of perjury, a declaration of ownership, which shall be retained by the clerk or person in charge of the property section.

The addition to subdivision (b)(1) inakes it clear that any party claiming ownership of the property may be accompanied by counsel to the

102. This assumes that the seizure conformed to the fourth amendment.

103. Cal. Penal Code $\S 1413$ (West Supp. 1976). If an application for return must be made before notice can be given and a restoration date set, there necessarily will be a delay between the date of application and the hearing clate. This time could be used to seeure a court order under sections 1408 to 1410 to prevent a property clerk decision in a particular case and to require a judicial determination of ownership.

104. See Skelly v. State Personnel Bd., 15 Cal. 3d 194, 210, 124 Cal. Rptr. 14, 25, 539 P.2d 774, 785 (1975).

Section 1413's procedures compare favorably to those followed in the issuance of a civil writ of possession against a thief still holding stolen property. The Penal Code provides for notice and an opportunity to be heard while the civil remedy does not. CAL. CODE CIV. PRO. $\$ 512.020$ (b) (West Supp. 1976), provides in part: "A writ of possession may be issued ex parte . . . if probable cause appears that ... [t]he defendant gained possession of the property by feloniously taking the property from the plaintiff." A writ of possession entitles the plaintiff to recover the property from the defendant. $\mathrm{CAL}$. CODE Crv. Pro. $\$ 512.070$ (West Supp. 1976). The writ is not available where stolen property is held by sonieone other than the thief. CAl. CoDe Crv. Pro. $\S 512.020$ (West Supp. 1976), Law Revision Comm'n Comment, 1973 Addition (the Commission noted that where stolen property was held by the police the remedies afforded by Penal Code sections 1407 to 1413 are to be used).

105. Proposed changes to the existing laws are italicized. Deletions are bracketed. Subsection (b) is divided into six subdivisions for the sake of clarity. 
section 1413 hearing or even represented by counsel if that party chooses not to attend the hearing. The requirement that the claimant also present proof of identity is deleted simce its purpose is to ensure that stolen property be returned only to the person named as the owner in the police report. ${ }^{106}$ This restriction is no longer necessary under the proposed version because the clerk is empowered to hear the claims of all persons having interests in the property.

(b)(2) Any person claiming ownership of property held pursuant to Section 1407 shall disclose the names of any other known persons who may have a claim against the property. The clerk or person in charge of the property section shall give notice by registered mail to all such claimants, to the person from whom custody of the property was taken, and to the person or persons accused of stealing or embezzling it, of the time and place of a hearing to determine the person to whom the property shall be delivered. At the time and place so designated the clerk or person in charge of the property section shall hear and receive evidence of ownership of the property concerned, and shall determine the disposition of the property. Such clerk or person in charge shall administer oaths and certify depositions which may be necessary to establish the ownership of any property held pursuant to Section 1407.

As proposed, subdivision (b)(2) specifies that a hearing before the police property clerk is required and establishes a procedure for the clerk to follow. This clarifies the present language, which requires notice and an opportunity to be leard, but which does not explicitly require a hearing. Subdivision (b)(2) mandates notice to all claimants, and recognizes that the person from whom custody of the property was taken and the person cliarged with the theft are not always the same. The provision that a copy of the claimant's proof of ownership accompany the notice has been deleted since all interested parties would have a right to be present when any proof of ownership is offered. Finally, this subdivision empowers the property clerk to receive evidence and administer oaths only for purposes of the section 1413 hearing. ${ }^{107}$

106. See Memorandum from Howard Janssen and Joe Busch to Dick Iglehart, supra note 8.

107. The chief remaining problem is the unwillingness of police departments to use the statute. Section 1413 is unwieldy at present. The rigidity of the hearing requirement may make it seem even more cumbersome. The absence of the proposed changes, however, may make the statute legally intolerable and may lead courts to read into it more strimgent requirements. If police departments are unwilling to employ section 1413 in either its present or proposed form, they must either hold the property and accept the rising costs of storing it or ignore the law and return the property to victims without notice to other interested parties. The first choice is untenable and the second could lead to civil liability in federal court for violating any claimant's due process rights under 42 U.S.C. \& 1983 (1970) (any person who, under color of state law, causes any other person to be deprived of any constitutional right is liable to the party imjured in an action at law or suit in equity). 
(b)(3) Any statement made by a person accused of stealing or embezzling property held pursuant to Section 1407 at a hearing conducted pursuant to the subsection, or the failure of such person to appear at such a hearing, shall not be admissible against such person in any trial for stealing or embezzling such property.

This proposed subdivision ensures that no penalty will be imposed on a person charged with a theft for disclaiming or failing to assert any ownership interests in the property to be returned.

(b)(4) Any delivery of property held pursuant to Section 1407 shall be without prejudice to the state or to the person accused of stealing or embezzling it or to the person frorn whom custody of the property was taken or to any other person who may have a claim against the property, and the person to whom such property is delivered pursuant to this subsection shall be so informed. No property released pursuant to this subsection, which is not perishable, shall be sold or otherwise knowingly disposed of by its owner until after the final determination of the action or proceedings for stealing or embezzling it.

(5) Prior to any delivery of property under this subsection, the clerk or person in charge of the property section shall make and retain a complete photographic record of such property.

(6) This subsection shall not apply to any property subject to forfeiture under any provision of law.

The proposed additional language in subdivision (b)(4) extends the protection afforded by the present "without prejudice" provision to all persons having an interest in the property and inandates, unlike the present version of the statute, that the successful claimant be informed that dehivery is without prejudice to all other claims. The proposed additional language also requires that the claimant be imstructed not to dispose of the property, thus ensuring that the property's function as evidence is protected.

(c) The magistrate before whom the complaint is laid, or who examines the charge against the person accused of stealing or embezzling the property, or the court before which a trial is had for steahing or embezzling it, shall upon application by a person to whom notice was required under the previous subsection, review the determination of the clerk or person in charge of the property section, and may order the property taken into the custody of the court upon a finding that the person to whom the property was delivered is not entitled thereto. Such court slall make its deternination in the same manner as a determination is made when the matter is before the court pursuant to Sections 1408 to 1410 , imclusive.

The addition to subsection (c) gives all persons affected by the property clerk's decision the right to request immediate judicial review of 
the decision before the criminal court having jurisdiction over the criminal case. This protects the fourteenth amendment rights of all persons having interests in the property.

\section{CoNCLUSION}

The procedure established by section 1413 is a nuch needed initial step toward protecting victims of crime. ${ }^{108}$ It allows a theft victim to quickly reclaim stolen property recovered by the pohice through an administrative, rather than a judicial, procedure. Administrative costs incurred by storing stolen property will be reduced, owners of property will not be deprived of their use and enjoyment for long periods after their recapture froin the thief, and citizens' perceptions of the criminal justice systein will hopefully be inproved. The approach taken by section 1413 is a constitutionally sound solution to the problen. Finally, the operational and mechanical problems found in it are not msurmountable.

The present section 1413, however, is deficient in certain respects. It does not specifically require that a hearing be held prior to release of the property, it does not establish a procedure for the property clerk to follow, it does not specifically allow a defendant to be represented by counsel at the property hearing, and it does not ensure that no penalty will be iniposed on a person charged with a theft for disclaiming or failing to assert any ownership interest im the property to be returned. Further, the present section does not adequately protect all persons with an interest in the property, nor does it adequately prevent the claimant froin disposing of the property prior to trial. Finally, the present section does not provide for immediate judicial review of the property clerk's decision to release property if requested by certain persons affected by that decision. The proposed amendments to section 1413 remedy these problems.

108. Due to the inadequacies in other states of the law concerning stolen property, a number of jurisdictions and law enforcement agencies have shown imterest in the provisions of section 1413. See Letter from Harold Boscovich (Assistant Director of the Victim/Witness Assistance Bureau) to Joseph Andrus (Deputy District Attorney, Multnomah County, Oregon), Sept. 24, 1975, on file at the California Law Review; Letter from Joseph J. Duffy (Staff Planner, Office of the Governor, State of Delaware) to Howard A. Janssen, July 1, 1975, on file at the California Law Review; Letter from Howard A. Janssen to John Morris (First Assistant District Attorney, Philadelphia, Pennsylvania), June 9, 1975, on file at the California Law Review; Letter from D.T. Christie (Associate Deputy Minister, Department of Justice, Canada) to State Senator Nicholas Petris, Sept. 12, 1975, on file at the California Law Review. 